\title{
THE EMPEROR'S LATER CLOTHES - AN EXPERIMENT IN STYLISTIC THEORY AND THE WRITING OF HENRY JAMES
}

David Smit

SOONER OR LATER, I think, all of us who admire the work of Henry James must confront the doubts we have at the back of our minds about the Master's late style. Sooner or later, as we stand among the cheering crowds watching the stately procession of the Master's prose, we must confront the precocious child who pipes up for all to hear during a lull in the tumult, not this time that the emperor has no clothes but that under the regal robes there is no emperor.

Critics have dealt with the obscurities and difficulties of James's late manner in a number of ways. Often they have denied that it is all that obscure; more often, they have justified it as being necessary to express James's subject matter. A good example of the first strategy is Charles Crow's essay on The Wings of the Dove. ${ }^{1}$ Crow analyzes seven passages from the novel to demonstrate the variety and flexibility of the prose. Crow succeeds very well with his chosen passages, but his choices are exceptions to James's usual style. Three are descriptive introductions to the main characters of the novel, and two are prolonged descriptions of actions. None of these passages features the most common elements of Jamesian proseabstract subjects, passive verbs, and a great many parenthetical interruptions-or the most common subject of that prose-a mind in fierce deliberation. When he does arrive at more typical examples of James's writing, Crow justifies much of the convoluted syntax by the second strategy; he argues that the prose dramatizes the subject matter. Here, for example, is a sentence from Book II of The Wings of the Dove:

On possessing himself of her arm he had made her turn, so that they faced afresh St. Mark's, over the great presence of which his eyes moved while she twiddled her parasol. ${ }^{2}$

And here is Crow's interpretation:

By its structure the sentence suspends the church, a "great presence," above Densher's awareness of its presence and Kate's action of trivial disregard. Something of the dramatic contrast, that is, in the attitudes of these two is caught and fixed for a moment in the structure of the sentence. ${ }^{3}$ 
Crow's method of explaining the passage is so common in literary criticism that we may forget for a moment that it is not literally true. Rather, it is based on a metaphor. James's sentence does not in fact "suspend" the church above Densher and Kate; it merely puts the clause about St. Mark's before the clause which tells what Densher and Kate do. Crow interprets the final clause of the sentence, a clause which modifies St. Mark's, as an analogy. Somehow the clause is dominated by the word it modifies in the same way that Densher and Kate are dominated by the cathedral that looms over them. Whether we accept Crow's interpretation depends entirely on our accepting the fitness of his metaphor.

All critical attempts to justify James's style by arguing that it is appropriate to the subject matter are based on metaphors. In his article "Late Manner, Major Phase" John Halverson begins by asserting that James did not revise away many of the mannerisms in the late style because he had become unaware of them. ${ }^{4}$ According to Halverson, the process of dictation caused James to develop an echoing conversational manner so that, ultimately, his characters acquired his voice. But Halverson also believes that the late style is necessary in spite of James's habits because of James's larger purpose- the exploration of the nature of evil: "The extraordinarily abstract diction, for example, is a product of the long and often painful attempt to grasp essences, somehow to get at the real thing." ${ }_{5}$ Halverson uses as an example a sentence from The Wings of the Dove which is just after the one cited by Crow; he believes the abstract diction of the sentence is essential to the epistemology of the scene: "She made out in the shade of the gallery the issue of the others from their place of purchase."6 To Halverson the essence of the people coming out of the shop is that they are "others," and the essence of where they have been is that it is "a place of purchase." Halverson goes on to explain James's syntax:

Language by its nature abstracts, isolates, and segments reality. In an attempt to cope with this limitation, James resorts to very large and inclusive language units full of qualification and parenthesis, and to fluid boundaries between sentences, boundaries made fluid by echoic repetition and associative trains. ${ }^{7}$

Like Crow, Halverson assumes that the form of language can somehow mirror or imitate what that language is referring to-that "place of purchase" is more accurate, more essential to James's purpose than the terms "shop" or "store" or even the name of a specific establishment, that Jamesian syntax with its abstractions, qualifications, and parentheses captures metaphorically James's vision of a world of essences perceived and analyzed in minute detail by a particular observer.

However, there are major difficulties with the critical assumption that James's diction captures the essence of his subject and with the more fundamental assumption that language can in fact mirror or imitate reality. The primary difficulty is that there is no reality outside of James's prose for the 
language to imitate. James's work is imaginative; it is a fiction. Thus, when critics posit an essence that the prose captures, they are also indirectly positing a hypothesis about what the work of art is trying to do; they are supplying an intention, if not to James, then at least to his work. The difficulty with such hypothetical intentions is that the only evidence for the intentions is the work of art itself and the examples which the critic cites. But the only justification for the examples which the critic cites is his hypothetical intention, and thus, the argument becomes circular. "Others" and "place of purchase" are just the right words to Halverson because they express the essence of what James was trying to express in The Wings of the Dove. But the only evidence that Halverson can offer for what James was trying to accomplish in the novel are the words "others" and "place of purchase."

Another difficulty with the critical assumption that language can accurately mirror or imitate reality is that, carried to its logical conclusion, the assumption destroys the concept of revision. All language becomes an integral constituent of the discourse in which it appears, and all revisions become different books. James may have revised his books to realize his intentions more accurately, but his originals must have therefore embodied a different intention, and thus, they are equally valid. In The Ambassadors, for example, James originally wrote this of Strether's musings about Chad in Chapter IX: "What sort of wretch had he expected Chad to be anyway?Strether had occasion to make the inquiry but was careful to make it in private." 8 For the New York Edition James changed the word "wretch" to "brute." If language mirrors or imitates reality as closely as many critics argue, then James is not just changing words; he is changing the very way Strether thinks about Chad. "Wretch" makes Strether's idea of Chad ambiguous. Chad may be a wretch because he causes suffering in other people or because he is suffering himself. But "brute" makes Strether's opinion unequivocal. A person is only a brute if he causes others to suffer. If a critic argues that "brute" is the very essence of what The Ambassadors is about in this passage, then "wretch" must have been the essence of something elsea different version of The Ambassadors. Either that, or the critic must argue that sometimes words capture essences and sometimes they do not, and the critic is left to demonstrate the particular circumstances under which words do or do not operate to capture essences, and he must do so in a way that avoids the circular reasoning which I have already pointed out.

Underlying both difficulties with the assumption that language can capture essences is a more fundamental notion about the way language worksthat words and syntax have a life of their own, which paradoxically makes them the exact conveyors of intention, an intention of which their author may be totally unaware. In the philosophy of aesthetics such a radical position is the belief of the organic or monistic theorists, such as Benedetto Croce and the New Critics. In opposition to the organic/monistic theory is 
the view that language is less exact and more pragmatic, that precise expression results from refining a number of options to a single choice but that even a final choice can never exactly reflect reality or a person's state of mind. Language in this dualistic view is by its very nature incapable of capturing essences and accurately imitating reality, and for this reason the dualistic theory is not held by critics who closely analyze texts. ${ }^{9}$

I find the dualistic theory, however, rather attractive. It seems to me that the theory is much more ready than the organic/monistic view to accept an author's word for what he intended, it is much more likely to explore alternatives to the particular phrasings in the text, to assume that a great deal in a text can't be explained or may be the result of a happy accident, and above all, it is much more likely to grant that particular readings of a text are merely tentative hypotheses. Therefore, I would like to explore a passage of Henry James's later style with the same interpretive hypothesis as an organic/monistic critic but without his desire to justify every pause and comma in James's work. I intend to suggest alternative ways in which James could have said the same thing while achieving the same effects. I do not mean thereby that I will have improved James's prose, although I might as well admit I think it can be improved at times. I only wish to explore the implications of the dualistic theory and plead for a broader range of critical response, not simply a justification of the work as it is but an exploration of alternatives.

A good essay to use as a source of interpretive hypotheses is Ian Watt's "The First Paragraph of The Ambassadors: An Explication."10 Watt's essay is the best stylistic criticism of James that I know; in fact, it is one of the best pieces of criticism that I know in the entire area of style. Watt finds seven major characteristics in the opening paragraph of The Ambassadors: "the delayed specification of referents"; the use of non-transitive verbs, abstract nouns, and "that"-clauses; a certain amount of "elegant variation" to avoid the repetition of pronouns; and a great many negatives. To Watt, these characteristics produce a number of interesting effects: a double perspective on the action of the novel-not only Strether's but also the narrator's-and an emphasis on mental as opposed to physical action.

\footnotetext{
Why does James say it the way he does? One effect is surely that, instead of a sheer stated event, we get a very special view of it; the mere fact that actuality has been digested into reported speech - the question 'was about his friend'-involves a narrator to do the job, to interpret the action, and also a presumed audience that he does it for ... Lastly, making the subject of the sentence 'question' rather then 'he,' has the effect of subordinating the particular act, to a much more general perspective: mental rather than physical, and subjective rather than objective; 'question' is a word which involves analysis of a physical event into terms of meaning and intention; it involves, in fact, both Strether's mind and the narrator's. The narrator's, because he interprets Strether's act...."
}

Despite the double perspective of the style, Watt believes that James's primary objective in The Ambassadors is to portray Strether's mental and subjec- 
tive state, to use "progressive and yet artfully delayed clarification" in order to "relate every event and every moment of life to the full complexity of its circumambient conditions." 12

Watt goes to great lengths to justify particular phrasings in the paragraph according to these criteria. Here, for example, is part of his explanation for the idiosyncrasies of the first sentence in the novel ("Strether's first question, when he reached the hotel, was about his friend ..."):

In the first part of the opening sentence, for example, the separation of subject'question'- from verb-'was' - by the longish temporal clause 'when he reached the hotel,' is no doubt a dislocation of normal sentence structure; but, of course, 'Strether' must be the first word of the novel: while, even more important, the delayed placing of the temporal clause, forces a pause after 'question' and thus gives it a very significant resonance. ${ }^{13}$

I find Watt's attempt to explain the slightest nuance in the sentence rather arbitrary. I see no reason why 'Strether' must necessarily be the first word of the novel, and I don't see any reason why placing the temporal clause after 'question' gives it more resonance than it would have at the beginning, as in "When Strether reached the hotel, his first question was about his friend..." Richard Ohmann has pointed out that much of the effect of Jamesian style results from the grammatical structure linguists call selfembedding. ${ }^{14}$ James tends to put his dependent clauses in the middle of sentences rather than at the beginning or at the end. But Watt obviously believes that embedded clauses are more than a mannerism or a typical characteristic; he believes that the embedded clauses can be justified thematically, that they resonate more than they would at the beginning or end of a sentence, that they more accurately portray Strether's mental state than they would at the beginning or end of a sentence. If Watt had examined his assumption apart from his particular examples, he might have had second thoughts. Are in fact embedded clauses a better, more accurate metaphor for mental processes than dependent clauses at the beginning and end of sentences? Perhaps, perhaps not. Who can say? Certainly a common view of mental life is that it is discontinuous, associative, and free-floating, but to assume that embedded clauses which break up the flow of a sentence capture this discontinuity better than initial or final clauses is at best a matter of opinion. I find it equally plausible to consider embedded clauses artificial and contrived since they do not occur as often as their counterparts at the beginning and end of sentences. This artificiality makes them the very antithesis of the mind's discontinuity and associate leaping. To claim that the form of language mirrors or imitates reality may be simply a way for a critic to declare his preference for certain kinds of metaphors.

Watt also spends a great deal of time in his essay showing how the style of the first paragraph of The Ambassadors introduces the themes of the novel. This strikes me as another weakness of stylistic criticism: it often chooses easy passages to interpret. By their very nature the beginnings and ends of 
fiction must introduce and conclude the themes, characters, and tone of the work as a whole. I think it a fair assumption that any beginning and ending of a novel can be justified in one way or another. The test of stylistic criticism, it seems to me, should be the interpretation of random passages, and not just to argue that such passages maintain a certain tone or style but to provide a justification of the language word by word as Watt does for an opening paragraph. Only then will we know if the fundamental assumptions of stylistic criticism are sound. Thus, I chose a passage to examine according to Watt's interpretive hypotheses by a fairly arbitrary method. I picked the middle narrative paragraph (the third of six) in the middle chapter (the eighteenth of thirty-six) of The Ambassadors. The passage describes Strether's thoughts about his changed circumstances just after he has learned that Sarah, Jim, and Mamie are coming to Paris to "re-enforce" his own attempts to retrieve Chad. In the preceding paragraph Strether meditates upon his new and deeper relationship to Mrs. Newsome, even though he is an ocean away from her. In the paragraph under consideration he goes back to visit Maria Gostrey regularly, and his talk is all about Mrs. Newsome. The paragraph is in three sections: the first presents Strether's thoughts about his new relationship to Mrs. Newsome vis-a-vis Maria, the second describes his changed relationship to Maria, and the third presents an elaborate metaphor to show Strether's new sense of himself. The first section of the paragraph is as follows:

(1)When he went back to Maria Gostrey it was for the change to something else. (2)And yet after all the change scarcely operated, for he talked to her of Mrs. Newsome in these days as he had never talked before. (3)He had hitherto observed in that particular a discretion and a law; considerations that at present broke down quite as if relations had altered. (4)They hadn't really altered, he said to himself, so much as that came to; for if what had occurred was of course that Mrs. Newsome had ceased to trust him, there was nothing on the other hand to prove that he shouldn't win back her confidence. (5)It was quite his present theory that he would leave no stone unturned to do so; and in fact if he now told Maria things about her that he had never told before this was largely because it kept before him the idea of the honour of such a woman's esteem. ${ }^{15}$

The aims of this kind of prose, according to Watt, are to reveal Strether's subjective mental state and to "relate every event and every moment of life to the full complexity of its circumambient conditions," and the primary means of achieving these goals is a "progressive, yet artfully delayed clarification." Now clearly the passage above does describe Strether's changing mental state; in fact, Strether is here thinking about how he has changed. The passage also progressively reveals yet artfully delays what Strether finally concludes about his changing relationships. The passage begins with Strether going back to Maria for some sort of change (sentence 1). And yet, Strether thinks, this change isn't really much of one at all (sentence 2). Thus, in the first two sentences James announces the theme of the paragraph, the nature and degree of Strether's change. The third sentence tells how the 
conversation between Strether and Maria about Mrs. Newsome is both the same, yet somehow different, and the fourth presents Strether's conclusion that his relationship to Mrs. Newsome has not really changed; even if she has lost faith in him, he can always win her back. This is an irony, of course, because in the very act of affirming that things have not changed with Mrs. Newsome, Strether admits that she may have stopped trusting him. The last sentence maintains the irony: Strether tells Maria things about Mrs. New. some that he had never told her before, a sign of Strether's changed relationship not only to Mrs. Newsome-before he had been more discreet (sentence 3)-but also to Maria-he is more open and easy with her. Yet despite all of these changes there is one thing that has not changed: Strether's concept of honor and his desire to maintain his relatonship with Mrs. Newsome. Thus, these five lines ring a variety of changes on the theme of change. The lines ironically play off against one another, all the while showing us how Strether comes to think of his relationship to Mrs. Newsome and to Maria. The passage does illustrate an advance in Strether's thinking, and the passage does progress while it artfully delays.

It is one thing, however, to describe the over-all theme and movement of a passage; it is another to justify all of the particular words and syntactic forms as stylistic critics try to do. I find three noteworthy characteristics in the passage, two of which are not in the first paragraph of the novel: 1) the use of logical or scientific terms - "law," "theory," "relations," "operated," 2) the use of "it was" and "there was," and 3) the use of conditionals in an unconventional way. Critics have commented on James's preference for logical terms before, but other than to assert that these terms are helpful in describing psychological activity, no one has provided a very good rationale for them. ${ }^{16}$ In the passage at hand these terms seem especially willful and mannered. Why did the change scarcely "operate," for example? Why isn't it scarcely noticable or scarcely in effect? Why is Strether's previous reluctance to discuss Mrs. Newsome with Maria a "law"? And why is Strether's decision to do everything to keep Mrs. Newsome's confidence a "theory"? I have no satisfactory answer to these questions, except to interpret the logical language as an ironic joke by the narrator at Strether's expense. "Law" may be an irony if we interpret it as a commentary on Strether's self-imposed discretion, but "theory" strikes me as simply the wrong word. Strether's belief that Mrs. Newsome has lost faith in him may be a theory, but his resolution to keep her confidence certainly isn't. Unless, of course, the narrator means to suggest that Strether's resolution is not firm, that what he will do in the future is a mere theory. This interpretation, however, calls into question the traditional view that James is largely sympathetic with Strether's point of view. If the traditional view is correct, the logical language in this passage undercuts our sympathy.

I find the use of "it was" and "there was" equally difficult to justify. Usually these constructions are used to assert a state of affairs; they are short 
forms of the expressions "it was a fact that" or "there was in fact." Now in the passage under consideration James may very well be trying to assert the reality of Strether's intentions. Both uses of "it was" assert the fact of Strether's particular mental state at the time. But, "it was" and "there was" are very wordy ways of asserting what is always implied in an English sentence, that what the sentence says is true. Suppose we revised the sentences containing "it was" and "there was" to eliminate them:

1. James: When he went back to Maria Gostrey it was for the change to something else.

Revision: He went back to Maria Gostrey for a change to something else.

4. James: . . for if what had occurred was of course that Mrs. Newsome had ceased to trust him, there was nothing on the other hand to prove that he shouldn't win back her confidence.

Revision: . . f for even if Mrs. Newsome had ceased to trust him, he had no proof that he shouldn't win back her confidence.

5. James: It was quite his present theory that he would leave no stone unturned to do so. ...

Revision: His present theory was that he would leave no stone unturned to do so....

What we lose in the revisions, of course, is the Jamesian flavor of the prose, but have we sacrificed subtle shades of meaning, delicate nuances of feeling? I do not think so. I also find the revisions just as rhythmic as the originals and indeed more forceful, although I must admit that they do not actively assert a state of affairs. Certainly the revisions meet Watt's criteria; they still present Strether's mind in progress, they still capture the complexity of surrounding conditions, and they are still artfully delayed, although not as much as the originals.

James's use of conditionals is as mannered as his use of "it" and "there." The first "if"-clause in the passage at hand is straightforward enough-it is a standard contrary-to-fact clause-but the second is ambiguous: ". . . and in fact if he now told Maria things about her that he had never told before this was largely because it kept before him the idea of the honor of such a woman's esteem." Clearly the "if'-clause here is not contrary-to-fact. The passage only makes sense if Strether is indeed telling Maria things about Mrs. Newsome he had never told before. Now an "if'-clause can be used to talk about past action that is not hypothetical, as in "if he took his vacation, he went duck hunting in Minnesota," but the action described in such constructions is habitual. "If" in this case functions like "when." In my example, every time the man takes his vacation he goes duck hunting in Minnesota. Does James mean to suggest then that Strether's latest talk of Mrs. Newsome is habitual? Perhaps. Sentence 2 tells us that Strether talked about Mrs. Newsome "in these days." But in any event the second "if'. 
clause comes only one short line after a clearly conditional "if"; the two clauses are close enough to suggest a parallelism, and thus, the shift in meaning is confusing, although perhaps for only a moment. The use of "when" would have eliminated the confusion.

If we assume the dualistic notion that all language is a tentative groping for meaning, that an author's intention can be realized in a number of alternative forms, we can also assume that we do no great violence to James's intention by casting his sentences in slightly different form. Here is a total revision of the passage under consideration, taking into account all of the difficulties I have pointed out. The question is whether the revision also meets Watt's justification of Jamesian prose: does it show Strether's mind in action? Does it convey the complexity of "circumambient conditions"? Is it progressively clearer yet artfully delayed?

\footnotetext{
He went back to Maria Gostrey for a change to something else. And yet the change was scarcely noticeable, for he talked to her of Mrs. Newsome in these days as he had never talked before. He had hitherto observed regarding Mrs. Newsome a discreet evasiveness, a consideration that now had broken down as if his relationship to her had altered. It hadn't really altered, he said to himself; for if Mrs. Newsome had ceased to trust him, he had no proof that he shouldn't win back her confidence. His present belief was that he would leave no stone unturned to do so; and in fact he now told Maria things about her that he had never told before because the telling kept before him the idea of the honour of such a woman's esteem.
}

The primary effect of my revision is to eliminate the studied ambiguity of many of James's constructions. James says that Strether went back to Maria Gostrey for "the change" to something else, which violates the convention that definite articles refer to previously identified antecedents. James has not identified what change he is talking about; his use of the construction makes the reader look for the change he is referring to. I use the more grammatically correct form "a change" to indicate that what the change is has not yet been specified. In addition, I have identified both what Strether's discretion is and what "that particular" is rather than leave them in Jamesian obscurity. I have eliminated "so much as that came to" as an empty colloquialism. I have changed "theory" to "belief" for reasons mentioned earlier, and I have changed the final "if-then" construction to a more direct statement of what Strether did. The revision is, I believe, clearer and more forceful than the original; it meets Watt's criteria, and it is still somehow Jamesian, although not as Jamesian as it was. The only defense I can think of for the original is that James wanted to be vaguely ambiguous. Whether we prefer the original or the revision is less a matter of meaning, it seems to me, than it is a matter of taste.

This last point, of course, would be severely condemned by the monistic critics. They would maintain that "studied ambiguity" is indeed "meaning" and that my revision does not mean the same thing at all, that in fact it is a different paragraph. The issue is crucial, and the two sides probably 
irreconcilable. But the issue must be met if we are finally to come to terms with James's late style. If we decide that all of the Master's later idiosyncrasies do in fact convey meaning, then the emperor's clothes do in fact display the emperor in all his glory. If, however, we decide that the Master's idiosyn. crasies are not very meaningful, that he could have said the same thing in a more direct and forceful way, then not all of the emperor's clothes are functional and may disguise the fact that there is nothing underneath. I want very much to see and appreciate the emperor in full splendor, but I still find much of his costume willfully ostentatious. And at times, when the sun shines brightly and every bauble and stitch glitters and flashes, I can't see the emperor at all. I only see his clothes.

\section{NOTES}

1 Charles Crow, "The Style of Henry James: The Wings of the Dove," Style in Prose Fiction: English Institute Essays, 1958, edited by Harold C. Martin (New York: Columbia University Press, 1959), pp. 172-189.

2 Henry James, The Wings of the Dove (New York: New American Library, 1964), p. 357.

3 Crow, p. 182.

4 John Halverson, "Late Manner, Major Phase," Sewanee Review, 79 (1971), pp. 214-231.

5 Ibid., 228.

6 James, p. 357.

7 Halverson, p. 229.

8 Henry James, The Ambassadors, edited by S.P. Rosenbaum (New York: W.W. Norton and Company, 1964), p. 109.

9 The primary proponents of the dualistic theory nowadays are specialists in composition, who argue the dualistic view to justify the concept of revision and the refining of meaning in the classroom. For a survey of three theories of style and a forceful argument for dualism, see Louis T. Milic, "Theories of Style and Their Implications for the Teaching of Composition," Contemporary Essays on Style, edited by Glen A. Love and Michael Payne (Glenview, Illinois: Scott, Foresman and Company, 1969), pp. 15-21.

10 Ian Watt, "The First Paragraph of The Ambassadors: An Explication," Contemporary Essays on Style, edited by Glen A. Love and Michael Payne (Glenview, Illinois: Scott, Foresman and Company, 1969), pp. 266-283.

11 Ibid., $271 \cdot 2$.

12 Ibid., 272, 276, 279.

13 Ibid., 276.

14 Richard Ohmann, "Generative Grammars and the Concept of Literary Style," Contemporary Essays on Style, edited by Glen A. Love and Michael Payne (Glenview, Illinois: Scott, Foresman and Company, 1969), pp.146-7.

15 James, The Ambassadors, p. 195.

16 See for example Dorothea Krook, "The Method of the Later Works of Henry James," London Magazine, 1 (1954), pp. 55-70, and Seymour Chatman, The Later Style of Henry James (Oxford: Basil Blackwell, 1972), pp. 9-10. 